\title{
NEW COMPOSITIONAL AND STRUCTURAL DATA VALIDATE THE STATUS OF JAMBORITE
}

\author{
LUCA BINDI ${ }^{\S}$ \\ Dipartimento di Scienze della Terra, Università degli Studi di Firenze, Via G. La Pira 4, I-50121 Firenze, Italy \\ ANDREW G. CHRISTY \\ Centre for Advanced Microscopy, and Department of Applied Mathematics, Research School of Physics and Engineering, \\ Australian National University, Canberra, ACT 0200, Australia \\ StUART J. MILLS \\ Geosciences, Museum Victoria, GPO Box 666, Melbourne, Victoria 3001, Australia
}

Marco E. CIRIOTTI

Associazione Micromineralogica Italiana, Via San Pietro 55, I-10073 Devesi-Ciriè, Torino, Italy

ERICA BITTARELLO

Dipartimento di Scienze della Terra, Università degli Studi di Torino, Via Tommaso Valperga Caluso, 35, I-10125 Torino, Italy

\begin{abstract}
Jamborite was originally described with the formula $\left(\mathrm{Ni}^{2+}, \mathrm{Ni}^{3+}, \mathrm{Fe}\right)(\mathrm{OH})_{2}\left(\mathrm{OH}, \mathrm{S}, \mathrm{H}_{2} \mathrm{O}\right)$ from Ca' de' Ladri and Monteacuto Ragazza near Bologna, and Castelluccio di Moscheda near Modena, Italy. Re-examination of the mineral from the type localities and Rio Vesale, Sestola, Val Panaro (Emilia-Romagna, Italy), led to the discovery of a crystal suitable for study by single-crystal and powder X-ray diffraction, SEM-EDS, and Raman spectroscopy. Jamborite crystallizes in the space group $R \overline{3} m$, with the unit-cell parameters $a 3.068(4) \AA$, $c$ 23.298(11) $\AA$, and $Z=3$. The structure refinement $\left(R_{1}=0.0818\right)$ showed that jamborite contains brucite-like sheets of edge-sharing octahedra $\left(\mathrm{Ni}^{2+}, M^{3+}\right)(\mathrm{O}, \mathrm{OH})_{6}$ with a distinctive double layer of partially occupied $\mathrm{H}_{2} \mathrm{O}$ molecules between them. Raman data indicate that the sulfur is present as sulfate rather than sulfide. The new analytical data were recalculated on the basis of $1(\mathrm{Ni}+\mathrm{Ca}+\mathrm{Co}+\mathrm{Fe})$ to give the formula $\left[\left(\mathrm{Ni}^{2+}{ }_{0.902} \mathrm{Ca}^{2+}{ }_{0.002}\right)\right.$ $\left.\left(\mathrm{Co}^{3+}{ }_{0.072} \mathrm{Fe}^{3+}{ }_{0.024}\right)\right]_{\Sigma 1.000}(\mathrm{OH})_{1.884} \mathrm{Cl}_{0.012}\left(\mathrm{H}_{2} \mathrm{O}\right)_{0.004}\left(\mathrm{SO}_{4}\right)_{0.100} \cdot 0.900 \mathrm{H}_{2} \mathrm{O}$. The sulfur occupancy was too low to be located in the refinement, but the $\approx 1: 1$ ratio of $M^{3+}: \mathrm{S}$ from the chemical analysis implies that $\mathrm{SO}_{4}{ }^{2-}$ replaces $\mathrm{OH}^{-}$in the brucite sheet rather than sitting in the interlayer space. The splitting of the $\mathrm{H}_{2} \mathrm{O}$ layer allows avoidance of short $\mathrm{SO}_{4}{ }^{2-} \cdots \mathrm{H}_{2} \mathrm{O}$ distances. Thus, jamborite is not a member of the hydrotalcite supergroup. Jamborite is redefined as $M^{2+}{ }_{1-x} M^{3+}{ }_{x}\left(\mathrm{OH}_{2-x}\left(\mathrm{SO}_{4}\right)_{x} \cdot n \mathrm{H}_{2} \mathrm{O}\right.$, where $M^{2+}$ is dominantly $\mathrm{Ni}, M^{3+}$ is dominantly $\mathrm{Co}, x \leq 1 / 3$ and probably $\leq 1 / 7(x=0.10$ for the neotype sample), and $n<(1-x)$. The low $M^{3+} / M^{2+}$ ratio relative to honessite and hydrohonessite and high Co content may explain the rarity of jamborite as an early alteration product of millerite. The redefinition of jamborite and designation of the neotype specimen from Rio Vesale have been approved by the Commission on New Minerals, Nomenclature and Classification (CNMNC), voting proposal 14-E.
\end{abstract}

Keywords: jamborite, brucite-like sheets, sulfate, redefinition, crystal structure, CNMNC.

$\S$ Corresponding author e-mail address: luca.bindi@unifi.it 


\section{INTRODUCTION}

Jamborite was originally described by Morandi \& Dalrio (1973) as $\left(\mathrm{Ni}^{2+}, \mathrm{Ni}^{3+}, \mathrm{Fe}\right)(\mathrm{OH})_{2}\left(\mathrm{OH}, \mathrm{S}, \mathrm{H}_{2} \mathrm{O}\right)$; they discovered it in ophiolitic rocks at $\mathrm{Ca}$ ' de' Ladri and Monteacuto Ragazza near Bologna, and Castelluccio di Moscheda near Modena, EmiliaRomagna, Italy. Jamborite typically forms green fibrous-lamellar pseudomorphs after millerite. The X-ray powder pattern indicated a hexagonal cell with the dimensions $a 3.07$ and $c 23.3 \AA$. In their recent review of the hydrotalcite supergroup, Mills et al. (2012) noted that, on the basis of original analytical data, the "...formula might be $\left[\left(\mathrm{Ni}^{2+}{ }_{6} \mathrm{Ni}^{3+}{ }_{2}\right)(\mathrm{OH})_{16}\right] \mathrm{S}^{2-} \cdot 4 \mathrm{H}_{2} \mathrm{O}$, but at the same time it must be noted that the coexistence of oxidized $\mathrm{Ni}^{3+}$ and reduced $\mathrm{S}^{2-}$ in an oxycompound is unusual, and that the pale green color of jamborite is not consistent with charge transfer between $\mathrm{Ni}^{2+}$ and $\mathrm{Ni}^{3+}$." Since the presence of $\mathrm{Ni}^{3+}$ and $\mathrm{S}^{2-}$ was not confirmed, and as the true formula of jamborite is unknown, Mills et al. (2012) designated jamborite as a "questionable species". Because of these findings, we embarked upon a multi-methodological approach to define the true composition and structure of jamborite and report the results herein.

Ideally, questions relating to the identity and definition of a mineral species should be settled by examination of the type material. Unfortunately, of the co-type specimens deposited at the University of Bologna from Ca' de' Ladri, Monteacuto Ragazza, and Castelluccio di Moscheda, too little material remained for samples to be released for study. This implied that a neotype specimen needed to be defined. We examined many specimens from the three cotype localities, but found none that yielded material suitable for single-crystal X-ray diffraction study. The only sample that did so was from Rio Vesale, Sestola, Val Panaro, very near the cotype locality Castelluccio di Moscheda. The Rio Vesale sample was identified as jamborite since its unit-cell parameters agreed well with the data of Morandi \& Dalrio (1973), while its major element composition was also in broad agreement with theirs. Thus, this material may serve as a neotype. Powder XRD, energy-dispersive X-ray spectrometry (EDS), and Raman spectroscopy verified that the same phase also occurs at the three original type localities. The neotype sample is deposited in the mineralogical collections of the Natural History Museum of the University of Florence, Italy, specimen number 3141/ I, and the single crystal mounted in epoxy, in the collections of the Museo Regionale di Scienze Naturali, Torino, number M/15850. The results and designation of the neotype specimen have been approved by the Commission on New Minerals, Nomenclature and Classification (CNMNC) of the International Mineralogical Association, voting proposal 14-E.
EXPERIMENTAL Methods

\section{Chemical analyses}

The crystal from Rio Vesale studied by singlecrystal X-ray diffraction (see below) was subsequently mounted into an epoxy tablet, polished, and quantitatively analyzed (23 points) with a scanning electron microscope using an X-ray energy-dispersive system (SEM-EDS). Specifically, we used a Stereoscan S360 Cambridge electron microscope with an Oxford Instruments INCA analyzer equipped with a PentaFET Link SATW detector. The working conditions were: working distance $25 \mathrm{~mm}$, accelerating voltage $15 \mathrm{kV}$, beam current $1.30 \mathrm{nA}$, and a live time of $50 \mathrm{~s}$. Since the sample damaged rapidly under the beam, it was not re-analyzed using wavelengthdispersive spectrometry.

\section{Raman spectroscopy}

The Raman spectrum of jamborite, of type honessite (NMNH \#117698) and of type hydrohonessite (WAM \#M77.1991b), were obtained using a micro/ macro Jobin Yvon LabRam HRVIS, equipped with a motorized $x-y$ stage and an Olympus microscope. The backscattered Raman signal was collected using a $50 \times$ objective; the Raman spectrum pertains to an unoriented crystal. We used the $632.8 \mathrm{~nm}$ line of an $\mathrm{He}-\mathrm{Ne}$ laser for excitation; the laser power was controlled by means of a series of density filters. The lateral and depth resolutions were about 2 and $5 \mu \mathrm{m}$, respectively. We calibrated the system using the $520.6 \mathrm{~cm}^{-1}$ Raman band of silicon before each experimental session. The spectra were collected with multiple acquisitions ( 2 to 10 ), with single counting times ranging between 5 and 30 seconds. Spectral manipulation such as baseline adjustment, smoothing, and normalization were performed using the Labspec 5 software package. Band-component analysis was undertaken using the Fityk software package (Wojdyr 2010), which enabled the type of fitting function to be selected and allows specific parameters to be fixed or varied accordingly. We recorded the spectrum using the LabSpec 5 program from 130 to $4000 \mathrm{~cm}^{-1}$; the results of the spectroscopic analysis are reported below.

\section{Single crystal X-ray diffraction, structure solution, and refinement}

Several crystal fragments were hand-picked from a rock sample (kindly provided by Massimo Batoni) collected at Rio Vesale, Modena, Italy. In the rock sample, jamborite occurs either as transparent single crystal pseudomorphs after millerite, or as green coatings on the walls of cavities lined by calcite, dolomite, and quartz. Several seemingly single crystals were selected and preliminarily examined with a 
Bruker-Enraf MACH3 single-crystal diffractometer using graphite-monochromatized $\mathrm{Mo} K \alpha$ radiation. Most did not show any diffraction peaks, implying that they are X-ray amorphous. Finally, one crystal $(30 \times 35 \times 130 \mu \mathrm{m}$ in size $)$ showed weak and broad peaks. Although the diffraction quality was not ideal, it was selected for a full data collection, which was done with an Oxford Diffraction Xcalibur 3 diffractometer (MoKo X-ray radiation) fitted with a Sapphire $2 \mathrm{CCD}$ detector. Intensity integration and standard Lorentz-polarization corrections were undertaken with the CrysAlis RED (Oxford Diffraction 2006) software package. Crystal shape and dimension optimization were performed with X-shape (Stoe \& Cie 1996), based on the Habitus program (Herrendorf 1993). The set of reflections was corrected for absorption via a Gaussian analytical method and averaged according to the $\overline{3} m$ point group. The only systematic absences were those referring to the $R$ lattice, so the structure solution was initiated in the space group $R \overline{3} m$. The position of the $\mathrm{Ni}$ atom (at the origin of the unit cell; Wyckoff position $3 a$ ) was determined from the threedimensional Patterson synthesis (Sheldrick 2008). Three-dimensional difference Fourier synthesis yielded the position of the remaining two $\mathrm{O}$ atoms (at positions $[0 ; 0 ; z]$ : Wyckoff site $6 c$ ). The full-matrix least-squares program SHELXL-97 (Sheldrick 2008) was used for the refinement of the structure. One oxygen site was found to be partially occupied $(44 \%)$. Hydrogen atoms could not be located. At the final stage, with isotropic atomic displacement parameters for all atoms and no constraints, the residual value settled at $R=0.0818$ for 45 independent observed reflections $[2 \sigma(I)$ level] and seven parameters. The very low (observed reflections)/(refined parameters) ratio prevented refinement of an anisotropic model of the structure. Neutral scattering curves for $\mathrm{Ni}$ and $\mathrm{O}$ were taken from the International Tables for X-ray Crystallography (Ibers $\&$ Hamilton 1974). Inspection of the differenceFourier map revealed maximum positive and negative peaks of $0.51 e^{-} / \AA^{3}(0.98 \AA$ from O1) and 0.53 $e^{-} / \AA^{3}(1.77 \AA$ from O2), respectively.

\section{RESUlts}

\section{Raman spectroscopy}

The Raman spectrum of neotype jamborite is dominated by an intense band at $527 \mathrm{~cm}^{-1}$ with a low-intensity band at $460 \mathrm{~cm}^{-1}$ (Fig. 1, Table 1). These bands may be attributed to $\nu_{4}\left(\mathrm{SO}_{4}\right)$ and $\nu_{2}\left(\mathrm{SO}_{4}\right)$, respectively, whereas the two bands at 973 and $1061 \mathrm{~cm}^{-1}$ may be attributed to $\nu_{1}\left(\mathrm{SO}_{4}\right)$ and $\nu_{3}\left(\mathrm{SO}_{4}\right)$, respectively. The presence of these four bands indicates that sulfate is present in jamborite, rather than sulfide, as described by Morandi \& Dalrio (1973). No bands were observed that could be attributed to $\mathrm{Si}-\mathrm{O}$ or $\mathrm{Si}-\mathrm{OH}$ vibrations. In the low-wavenumber region, jamborite displays two bands at 167

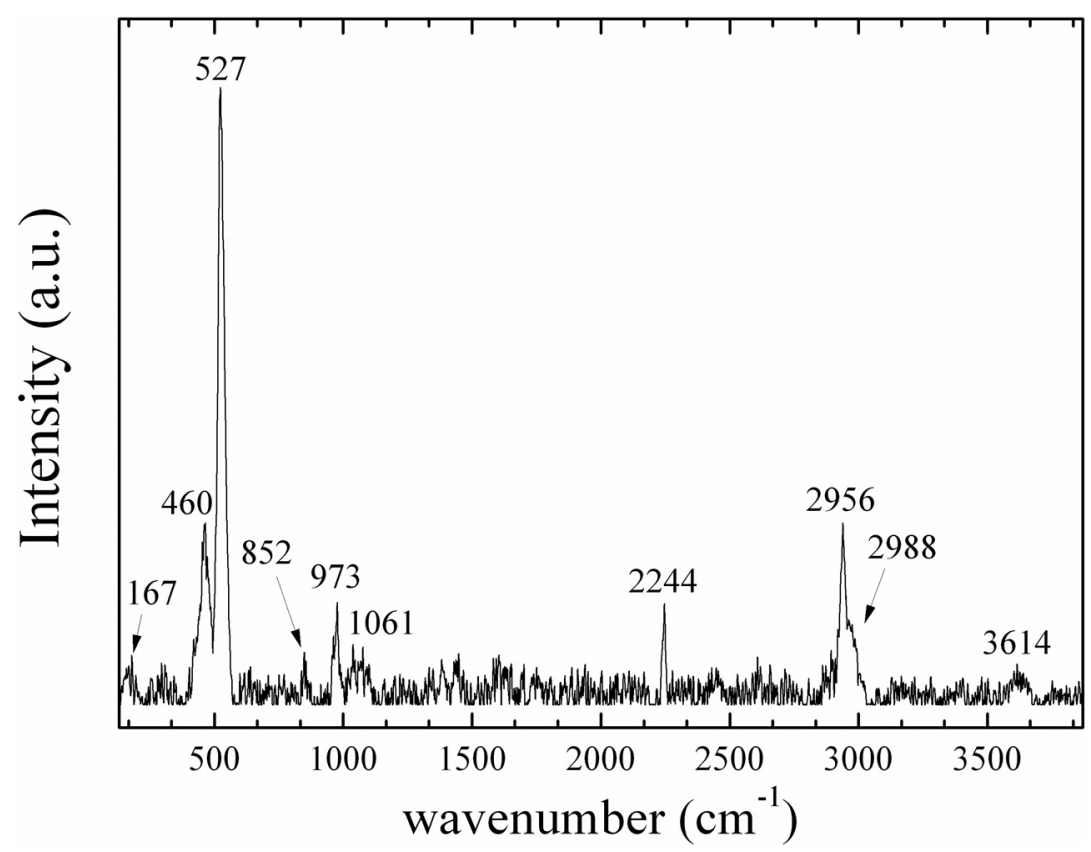

FIG. 1. Raman spectra of jamborite in the $130-4000 \mathrm{~cm}^{-1}$ region. 
TABLE 1. RAMAN BANDS $\left(\mathrm{cm}^{-1}\right)$ AND ASSIGNMENTS FOR JAMBORITE, HONESSITE, AND HYDROHONESSITE

\begin{tabular}{|c|c|c|c|}
\hline jamborite & honessite & hydrohonessite & assignment \\
\hline 167 & & \multirow{3}{*}{297} & lattice vibrations of $\mathrm{Ni} / \mathrm{Co}-\mathrm{O}$ \\
\hline 286 & 302 & & lattice vibrations of $\mathrm{Ni} / \mathrm{Co}-\mathrm{O}$ \\
\hline 460 & 468 & & $\nu_{2}\left(\mathrm{SO}_{4}\right)$ \\
\hline 527 & 528 & \multirow[t]{3}{*}{533} & $\nu_{4}\left(\mathrm{SO}_{4}\right)$ \\
\hline 628 & & & $\mathrm{E}_{\mathrm{g}}(\mathrm{T})$ mode $\mathrm{Ni} / \mathrm{Co}-\mathrm{OH}$ \\
\hline 852 & 826 & & unassigned \\
\hline 973 & 979 & \multirow[t]{2}{*}{976} & $\nu_{1}\left(\mathrm{SO}_{4}\right)$ \\
\hline 1061 & 1032 & & $\begin{array}{l}\nu_{3}\left(\mathrm{SO}_{4}\right) \\
\mathrm{H}-\mathrm{O}-\mathrm{H} \text { bendina mode }\end{array}$ \\
\hline 2874 & & 2512 & Stretching mode of $\mathrm{H}_{2} \mathrm{O}$ molecules \\
\hline 2956 & 2950 & 2612 & Stretching mode of $\mathrm{H}_{2} \mathrm{O}$ molecules \\
\hline 2988 & & 2768 & Stretching mode of $\mathrm{H}_{2} \mathrm{O}$ molecules \\
\hline 3614 & 3573 & 3621 & Stretching mode of $\mathrm{OH}$ groups \\
\hline & 3626 & 3647 & Stretching mode of $\mathrm{OH}$ groups \\
\hline
\end{tabular}

and $286 \mathrm{~cm}^{-1}$. These bands are assigned to lattice vibrations of $\mathrm{Ni} / \mathrm{Co}-\mathrm{O}$.

In the region between 2500 and $4000 \mathrm{~cm}^{-1}$ (hydroxyl-stretching region), the spectrum displays a considerable amount of noise; some bands show low intensity, but it is possible to observe a broad envelope of overlapping bands centered upon $2900 \mathrm{~cm}^{-1}$. Band-component analysis enables modes to be resolved, with three intense bands at 2874, 2956, and $2988 \mathrm{~cm}^{-1}$. Another broad and weak band is observed at $3614 \mathrm{~cm}^{-1}$.

In order to confirm the presence of sulfate in jamborite, we investigated the type samples of honessite $\left(\left[\mathrm{Ni}_{1-x} \mathrm{Fe}^{3+}{ }_{x}(\mathrm{OH})_{2}\right]\left(\mathrm{SO}_{4}\right)_{x / 2} \cdot n \mathrm{H}_{2} \mathrm{O}\right.$, where $x<0.5$ and $n<3 x / 2$; NMNH \#117698) and hydrohonessite $\left(\left[\mathrm{Ni}_{1-x} \mathrm{Fe}^{3+}{ }_{x}(\mathrm{OH})_{2}\right]\left(\mathrm{SO}_{4}\right)_{x / 2} \cdot n \mathrm{H}_{2} \mathrm{O}\right.$, where $x<0.5$ and $n>3 x / 2$; WAM \#M77.1991b). For honessite, the sulfate bands were observed at 468, 528, 979, and $1032 \mathrm{~cm}^{-1}$, whereas for hydrohonessite, they were observed only at 533 and $976 \mathrm{~cm}^{-1}$.

\section{Chemical analyses}

Results of the EDS analysis of the mounted jamborite crystal are reported in Table 2 . In addition to the analytes listed, $\mathrm{Mg}$ was sought but not found above the detection limit. The crystal was also analyzed for oxygen, but the result is not shown in the table, as the calculated $\mathrm{O}$ content is preferred for recalculation of the formula, given the large corrections and uncertainties involved in quantifying the measured values of the oxygen content. Oxygen atomic percentages were $23.42-38.01 \mathrm{wt} . \%$, mean $=$ 31.06 wt. $\%$ and standard deviation 4.68 wt. $\%\left(\mathrm{SiO}_{2}\right.$ standard), which may be compared with the 41.57 wt. $\%$ oxygen calculated below. The data in Table 2 are broadly in accord with the less complete analysis of Morandi \& Dalrio (1973), who gave (wt.\%) $\mathrm{Mg}<$ $0.2 \%$, S $3.5 \%$, Fe $0.9 \%$, Co $1.9 \%$, and $\mathrm{Ni}$ in the interval $42.0-49.4 \%$.

The analytical results were initially recalculated making the following assumptions:

1) The mean atomic ratio $\mathrm{S}: \mathrm{Si}$ in the EDS analyses is about 4:1. However, the Raman spectrum showed sulfate bands but no silicate bands. Hence, the small amount of $\mathrm{Si}$ was attributed to a silica impurity (only about 1 wt.\% of the total sample, and unlikely to be detected by XRD) and excluded. The Ca was included with $\mathrm{Ni}$.

2) Nickel can occur only in the $2+$ oxidation state, as $\mathrm{Ni}^{3+}$ is known only from a small number of synthetic compounds formed under very oxidizing conditions, and has never been proven to be present in a mineral.

3) Conversely, Co and Fe may be in the $2+$ or $3+$ states. Iron oxidizes more readily than $\mathrm{Co}$; for $\mathrm{Co}^{3+}$ to be present, all $\mathrm{Fe}$ is assumed to be $\mathrm{Fe}^{3+}$.

As indicated above, input from other techniques was used to further constrain the treatment of the analytical data. The Raman spectrum indicates that $\mathrm{S}$ is present as $\mathrm{SO}_{4}{ }^{2-}$, but shows no evidence of $\mathrm{CO}_{3}{ }^{2-}$ or $\mathrm{S}^{2-}$. Hence, sulfur is in the $6+$ oxidation state.

Detailed consideration of these analytical data in conjunction with the structure refinement and crystalchemical constraints allow us to construct a structure model for jamborite, which is derived in detail below. The model implies that the maximally hydrated 
TABLE 2. EDX ANALYSIS OF JAMBORITE

\begin{tabular}{|c|c|c|c|c|c|}
\hline Element & wt.\% el. (mean of 23) & Range & SD & Standard & $\begin{array}{c}\text { Atoms per } 1 \\
(\mathrm{Ni}+\mathrm{Co}+\mathrm{Fe}+\mathrm{Ca})\end{array}$ \\
\hline S & 2.57 & $1.87-3.28$ & 0.34 & $\mathrm{FeS}_{2}$ & 0.09995 \\
\hline $\mathrm{Cl}$ & 0.35 & $0.21-0.55$ & 0.08 & $\mathrm{KCl}$ & 0.01231 \\
\hline $\mathrm{Si}$ & 0.58 & $0.06-1.59$ & 0.54 & $\mathrm{SiO}_{2}$ & 0.02574 \\
\hline $\mathrm{Ca}$ & 0.06 & $0.01-0.17$ & 0.04 & $\mathrm{CaSiO}_{3}$ & 0.00187 \\
\hline $\mathrm{Fe}$ & 1.08 & $0.47-1.73$ & 0.37 & Fe metal & 0.02411 \\
\hline Co & 3.41 & $0.74-4.95$ & 1.09 & Co metal & 0.07215 \\
\hline $\mathrm{Ni}$ & 42.46 & $31.85-46.87$ & 3.35 & Ni metal & 0.90188 \\
\hline Subtotal & 50.51 & & & & \\
\hline $\mathrm{O}(\text { calc. })^{\star}$ & 17.88 & & & & 1.39331 \\
\hline $\mathrm{H}_{2} \mathrm{O}$ (calc. $)^{\dagger}$ & 26.67 & & & & 1.84577 \\
\hline Total & 95.06 & & & & \\
\hline
\end{tabular}

* Oxygen required to balance charge of analysed cations. ${ }^{\dagger}$ Additional $\mathrm{H}_{2} \mathrm{O}$ required to fit maximally hydrated formula derived from structure model.

stoichiometry is $\mathrm{Ni}^{2+}{ }_{1-x} M^{3+}{ }_{x}(\mathrm{OH})_{2-x}\left(\mathrm{SO}_{4}\right)_{x}(1-x) \mathrm{H}_{2} \mathrm{O}$. For such a stoichiometry, the most sensible method of recalculating the formula, in the absence of direct determination of $\mathrm{H}_{2} \mathrm{O}$ content and cation oxidation states, is as follows.

1) Use the atomic ratio $\mathrm{S} /(\mathrm{Ni}+\mathrm{Co}+\mathrm{Fe})$ to obtain the parameter $x$ in the formula above.

2) Recalculate to a convenient fixed number of $(\mathrm{Ni}+\mathrm{Co}+\mathrm{Fe})$.

3) Assume that $\mathrm{Fe}$ and then $\mathrm{Co}$ are trivalent, up to a maximum set by the number of $\mathrm{SO}_{4}{ }^{2-}$.

4) Assume that $\mathrm{Cl}^{-}$substitutes for $\mathrm{OH}^{-}$.

5) Initially, assume $(2-x)\left(\mathrm{OH}^{-}+\mathrm{Cl}^{-}\right)$per octahedrally coordinated cation, but replace some of the $\mathrm{OH}^{-}$with $\mathrm{O}^{2-}$ or with $\mathrm{H}_{2} \mathrm{O}$ as required to maintain electroneutrality.

6) Add additional $\mathrm{H}_{2} \mathrm{O}$ to give the maximum $\mathrm{H}_{2} \mathrm{O}$ content allowed by the formula above.

For the analysis in Table 2, the ratio $x=\mathrm{S} /(\mathrm{Ni}+\mathrm{Co}+$ $\mathrm{Fe}+\mathrm{Ca})=0.0999$, and we recalculated the numbers of atoms to $1(\mathrm{Ni}+\mathrm{Co}+\mathrm{Fe}+\mathrm{Ca})$. Following the steps listed above, we obtained the formula: $\left[\left(\mathrm{Ni}^{2+}{ }_{0.902} \mathrm{Ca}^{2+}{ }_{0.002}\right)\right.$ $\left.\left(\mathrm{Co}^{3+}{ }_{0.072} \mathrm{Fe}^{3+}{ }_{0.024}\right)\right]_{\Sigma 1.000}(\mathrm{OH})_{1.884} \mathrm{Cl}_{0.012}\left(\mathrm{H}_{2} \mathrm{O}\right)_{0.004}$ $\left(\mathrm{SO}_{4}\right)_{0.100} \cdot 0.900 \mathrm{H}_{2} \mathrm{O}$. All $\mathrm{Fe}$ and $\mathrm{Co}$ are trivalent, with $\mathrm{Co}$ predominating (atomic $\mathrm{Co} / \mathrm{Fe}=3$ ). Although the sulfate content appears to be minor in the formula expressed this way, it is likely that there is strong two-dimensional ordering of $\mathrm{SO}_{4}$ groups as discussed below, as well as of divalent and trivalent octahedral cations, but such order does not propagate between layers to produce a superstructure in X-ray diffraction. Such low-dimensional order is well documented for the structurally related hydrotalcite supergroup of minerals (Mills et al. 2012, Génin et al. 2014). By analogy with species of the woodwardite group in the hydrotalcite supergroup (Mills et al. 2012), it is reasonable to define jamborite and any related minerals that may be discovered in the future on the basis of the dominant divalent and trivalent octahedrally coordinated cations. The analytical data indicate that $\mathrm{Ni}^{2+}$ and $\mathrm{Co}^{3+}$ are the dominant octahedral species in jamborite, such that the ideal formula is $\mathrm{Ni}^{2+}{ }_{1-x} \mathrm{Co}^{3+}{ }_{x}$ $(\mathrm{OH})_{2-x}\left(\mathrm{SO}_{4}\right)_{x} \cdot n \mathrm{H}_{2} \mathrm{O}$. In the material analyzed, $x$ is approximately 0.1 , although in the discussion below, we indicate that $x \leq 1 / 3$ (and probably $\leq 1 / 7$ ), with $n \leq(1-x)$.

\section{Crystal-structure model for jamborite}

Refinement of the single-crystal XRD data for jamborite indicates that the structure contains brucitelike $M_{n} X_{2 n}$ layers [with bond distances $M-X=1.977$ (7) $\AA$, where $M=\mathrm{Ni}$, Co, and $\mathrm{Fe}$, and $X$ is predominantly $\mathrm{OH}^{-}$, with additional species $\left(\mathrm{SO}_{4}^{2}, \mathrm{H}_{2} \mathrm{O}\right)$ located in the interlayers. Thus, jamborite bears a strong structural and compositional resemblance to the woodwardite-group mineral honessite, $\mathrm{Ni}^{2+}{ }_{1-x} \mathrm{Fe}^{3+}{ }_{x}$ $(\mathrm{OH})_{2}\left(\mathrm{SO}_{4}\right)_{x / 2} \cdot n \mathrm{H}_{2} \mathrm{O}$ (Mills et al. 2012). Like other members of the hydrotalcite supergroup, the excess positive charge due to $M^{3+}$ in the hydroxide layer of honessite is balanced by interlayer anions such that there is $2 \mathrm{M}^{3+}$ for every $\mathrm{SO}_{4}{ }^{2-}$. However, jamborite differs from honessite in that the interlayer spacing is narrower (7.46 $\AA$ as opposed to $8.90 \AA$ ), and the refined average structure shows two distinct layers of atoms between each pair of brucite-like layers. Furthermore, the analytical data indicate that the potential $\mathrm{M}^{3+}$ cations $\left(\mathrm{Co}\right.$ and $\mathrm{Fe}$ ) and $\mathrm{SO}_{4}{ }^{2-}$ are almost perfectly in a $1: 1$ ratio in jamborite, rather than the 2:1 ratio typical of "layered double hydroxide" phases such as honessite. This in turn suggests that charge balance in jamborite is achieved not through $\mathrm{SO}_{4}{ }^{2-}$ occurring as isolated groups in the 
interlayer space, but through a hydroxide of the brucite-like layer being replaced by an apical oxygen atom of the sulfate tetrahedron. Sulfate tetrahedra are strongly bound to an otherwise brucite-like layer in this fashion in minerals such as spangolite, $\mathrm{Cu}_{6} \mathrm{Al}$ $(\mathrm{OH})_{12}\left(\mathrm{SO}_{4}\right) \mathrm{Cl} \cdot 3 \mathrm{H}_{2} \mathrm{O}$ (Hawthorne et al. 1993). Incorporation of the sulfate group into the "brucite" layer explains the contraction of the jamborite interlayer space relative to honessite, in which a completely separate sulfate tetrahedron is linked to the "brucite" layers only through hydrogen bonds. Thus, jamborite, like spangolite, lies outside the hydrotalcite supergroup as defined by Mills et al. (2012), but is nevertheless a member of a broader family of brucite-derived layered structures. The inferred stoichiometry of jamborite is
$\mathrm{Ni}^{2+}{ }_{1-\mathrm{x}} M^{3+}{ }_{\mathrm{x}}(\mathrm{OH})_{2-\mathrm{x}}\left(\mathrm{SO}_{4}\right)_{\times} \cdot n \mathrm{H}_{2} \mathrm{O}$, where the analytical data show that $x$ is approximately equal to 0.1 . The maximum value of $n$ is discussed below.

The X-ray unit cell of jamborite has $a \approx 3 \AA$, implying that there is only one octahedrally coordinated cation $(\mathrm{Ni}, \mathrm{Co}$, and $\mathrm{Fe}$ ) per unit mesh in each brucite-like layer, and that there is no three-dimensional long-range order involving $M^{3+}$ or $\mathrm{SO}_{4}{ }^{2-}$. The two layers of interlayer atoms located in the structure refinement are too strongly scattering to correspond to very sparsely occupied sulfate groups, and hence must be $\mathrm{H}_{2} \mathrm{O}$ molecules. The refinement indicates that these lie at similar $x$ and $y$ coordinates to the hydroxide groups of the "brucite" layers immediately above and below them (Fig. 2).
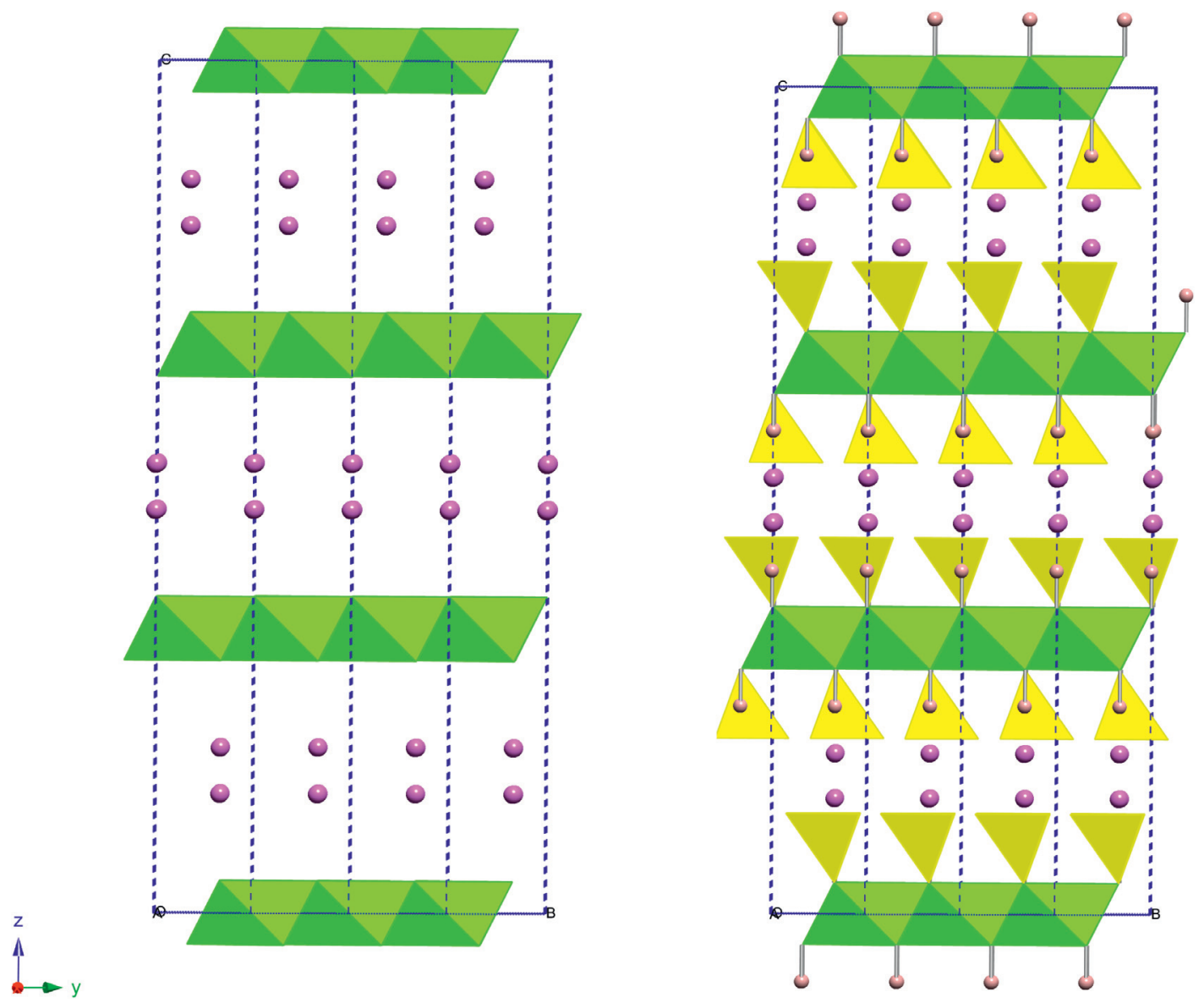

FIG. 2. The jamborite structure, viewed down the $\mathbf{x}$ direction. (left) The atoms located in the crystal-structure refinement. Sheets of edge-sharing $(\mathrm{Ni}, \mathrm{Co}) \mathrm{O}_{6}$ octahedra (green) stack in an $A B C$ pattern to give a three-layer rhombohedral unit cell. The interlayer spaces contain two layers of scatterers (pink); these are deduced to be $\mathrm{H}_{2} \mathrm{O}$ molecules at $\sim 50 \%$ occupancy. (right) A more complete depiction of the structure as deduced here. The majority of anions bonded to $(\mathrm{Ni}, \mathrm{Co})$ are $\mathrm{OH}^{-}$, for which the $\mathrm{H}$ atoms are indicated (small spheres). However, about $5 \%$ of the $\mathrm{OH}^{-}$are replaced by the apical $\mathrm{O}^{2-}$ ligands of $\mathrm{SO}_{4}{ }^{2-}$ groups (yellow tetrahedra). 

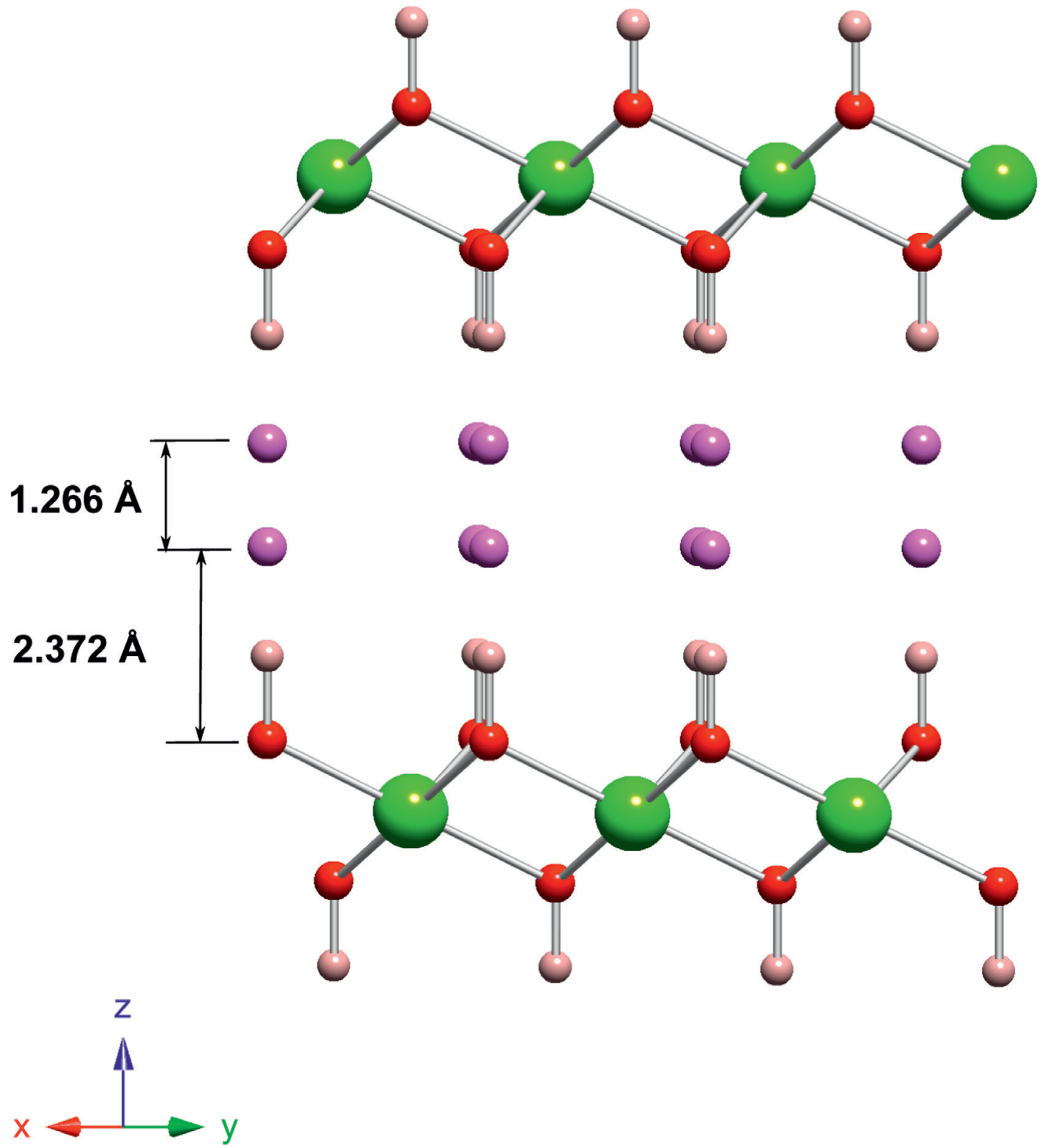

FIG. 3. The structure of jamborite with sulfate groups omitted. The short distance between the two $\mathrm{H}_{2} \mathrm{O}$ sites implies that only the upper or lower site in each pair can be occupied. The $\mathrm{O}-\mathrm{H}^{\cdots} \mathrm{H}_{2} \mathrm{O}$ distance shown is also short, but becomes reasonable if the $\mathrm{H}_{2} \mathrm{O}$ molecules are actually displaced slightly from their average positions.

Suppose we represent anion coordinates by $A=$ $[0 ; 0 ; z], B=[2 / 3 ; 1 / 3 ; z]$, and $C=[1 / 3 ; 2 / 3 ; z]$, and octahedral cation coordinates by the corresponding Greek letters $\alpha, \beta$, and $\gamma$. Then, between two successive brucite-type layers $A \beta C$ and $C \alpha B$, the $\mathrm{H}_{2} \mathrm{O}$ molecules are at the $C$ positions. In the refinement, the distances between oxygen atoms along the $\mathbf{z}$ direction across the interlayer $\mathrm{OH} \cdots \mathrm{H}_{2} \mathrm{O} \cdots \mathrm{H}_{2} \mathrm{O} \cdots \mathrm{OH}$ are $2.372,1.266$, and $2.372 \AA$ (Fig. 3). Clearly, the two $\mathrm{H}_{2} \mathrm{O}$ positions cannot be occupied simultaneously. These must be mutually exclusive sites with $\leq 50 \%$ occupancy, with $\mathrm{H}_{2} \mathrm{O}$ located at either the lower or upper position, but not both. The $2.372 \AA$ distance is also very short for an $\mathrm{O}-\mathrm{H} \cdots \mathrm{O}$ hydrogen-bonded distance. The usual 
TABLE 3. STRUCTURE MODEL FOR JAMBORITE, $\mathrm{Ni}^{2+}{ }_{1-x} \mathrm{M}^{3+}{ }_{x}(\mathrm{OH})_{2-x}\left(\mathrm{SO}_{4}\right)_{x} \cdot n \mathrm{H}_{2} \mathrm{O}$

\begin{tabular}{lcccc}
\hline Site & Occupancy & $x$ & $y$ & $z$ \\
\hline$M$ & $0.9 \mathrm{Ni}^{2+}+0.1(\mathrm{Co}, \mathrm{Fe})^{3+}$ & 0 & 0 & 0 \\
$\mathrm{O} 1$ & $1.00 \mathrm{O}$ & $1 / 3$ & $2 / 3$ & 0.0377 \\
$\mathrm{H}^{*}$ & $0.95 \mathrm{H}$ & $1 / 3$ & $2 / 3$ & 0.0820 \\
$\mathrm{~S}^{*}$ & $0.05 \mathrm{~S}$ & $1 / 3$ & $2 / 3$ & 0.1003 \\
$\mathrm{O}^{*}$ & $0.05 \mathrm{O}$ & 0.0740 & 0.9260 & 0.1212 \\
$\mathrm{Ow}$ & $0.45 \mathrm{O}$ & $1 / 3$ & $2 / 3$ & 0.1395 \\
\hline
\end{tabular}

Note: Space group $R \overline{3} m$, a 3.068(4) $\AA$, c 23.298(11) $\AA$, and $Z=3$. The compositional parameter $x$ has been set at 0.1 , and $n$ at $(1-x)$ (see text for explanation). Positions of asterisked sites have been calculated from assumed bond lengths and directions. Other coordinates correspond to those of the structure refinement

bond valences of approximately 0.8 valence units (v.u.) for $\mathrm{O}-\mathrm{H}$ and 0.2 v.u. for $\mathrm{H} \cdots \mathrm{O}$ would correspond to a O-H...O distance of about $2.7 \AA$ (Brown \& Altermatt 1985). However, this distance can be increased by small sideways displacements of the $\mathrm{H}_{2} \mathrm{O}$ molecule about these average positions.

Above a "brucite" layer $A \beta C$, the $\mathrm{S}$ of the sulfate group in our model for jamborite must also lie at a
$C$ position, vertically above the sulfate oxygen that is replacing a hydroxide. Thus, the oxygen atoms of the $\mathrm{SO}_{4}{ }^{2-}$ group that point into the interlayer cannot be at $C$ positions, but must be at approximate $A$ or $B$ positions; the position close to $B$, above the octahedrally coordinated cation, would be electrostatically the most favorable. If we assume that the sulfate $\mathrm{S}-\mathrm{O}$ distance is close to the grand average value of 1.459
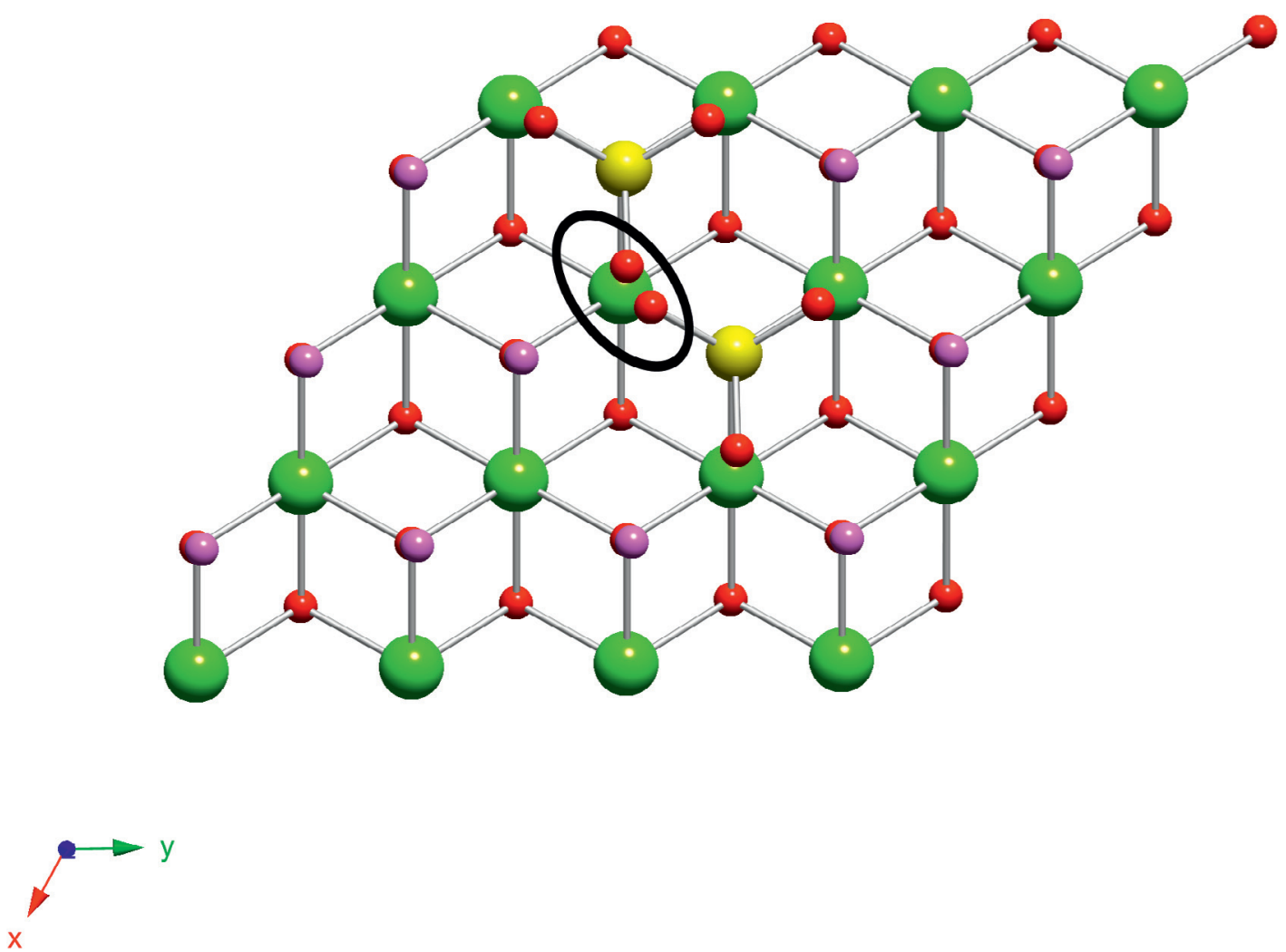

FIG. 4. Two similarly oriented sulfate groups cannot replace adjacent hydroxide groups of the same layer. The ellipse indicates the $0.681 \AA$ distance between oxygen atoms that would result. 


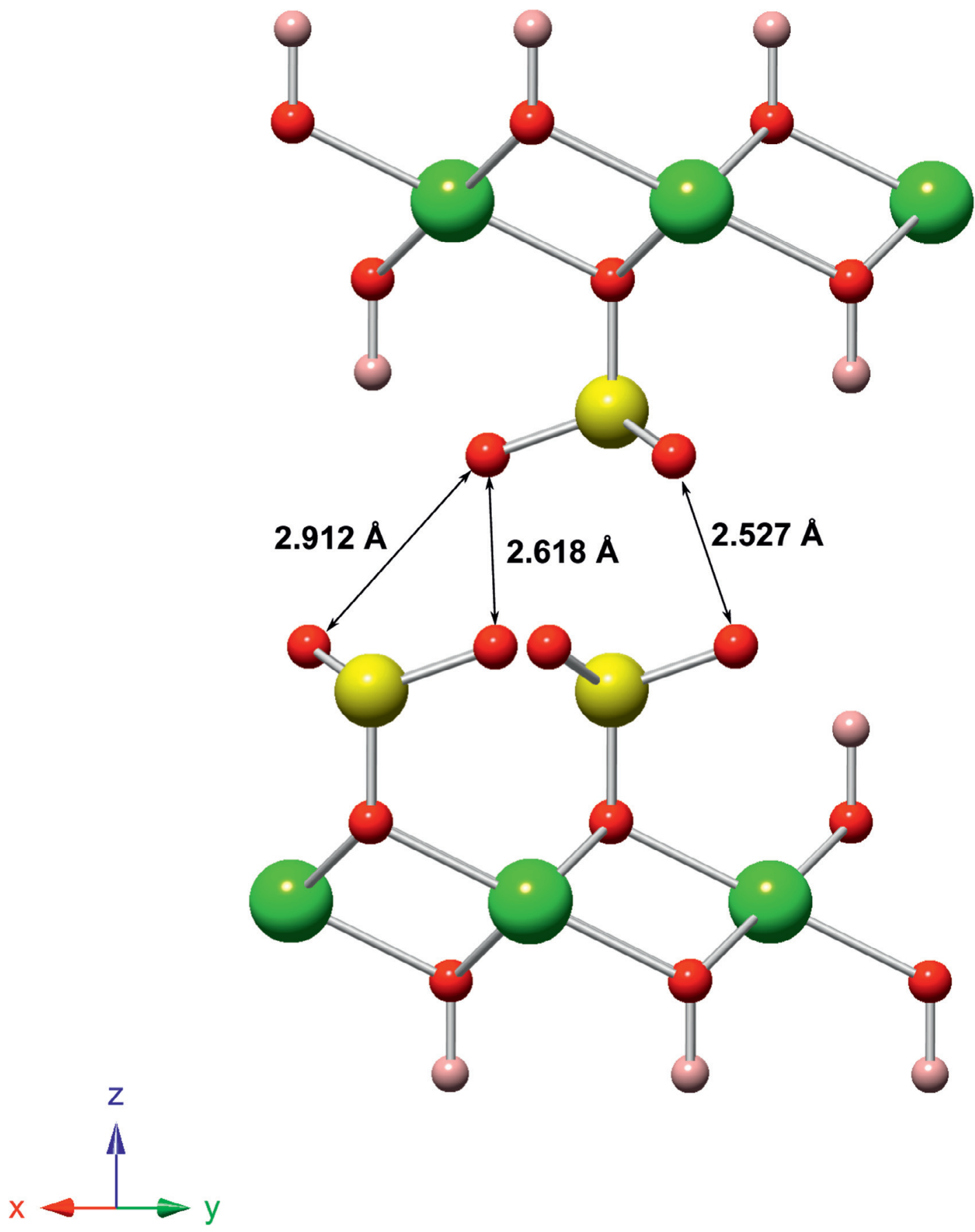

FIG. 5. If the upper sulfate group is present, then the sulfate tetrahedron immediately below it cannot be occupied owing to unrealistically short $\mathrm{O} \cdots \mathrm{O}$ distances. However, other sulfate positions in the lower layer are sufficiently far away to be occupied. 


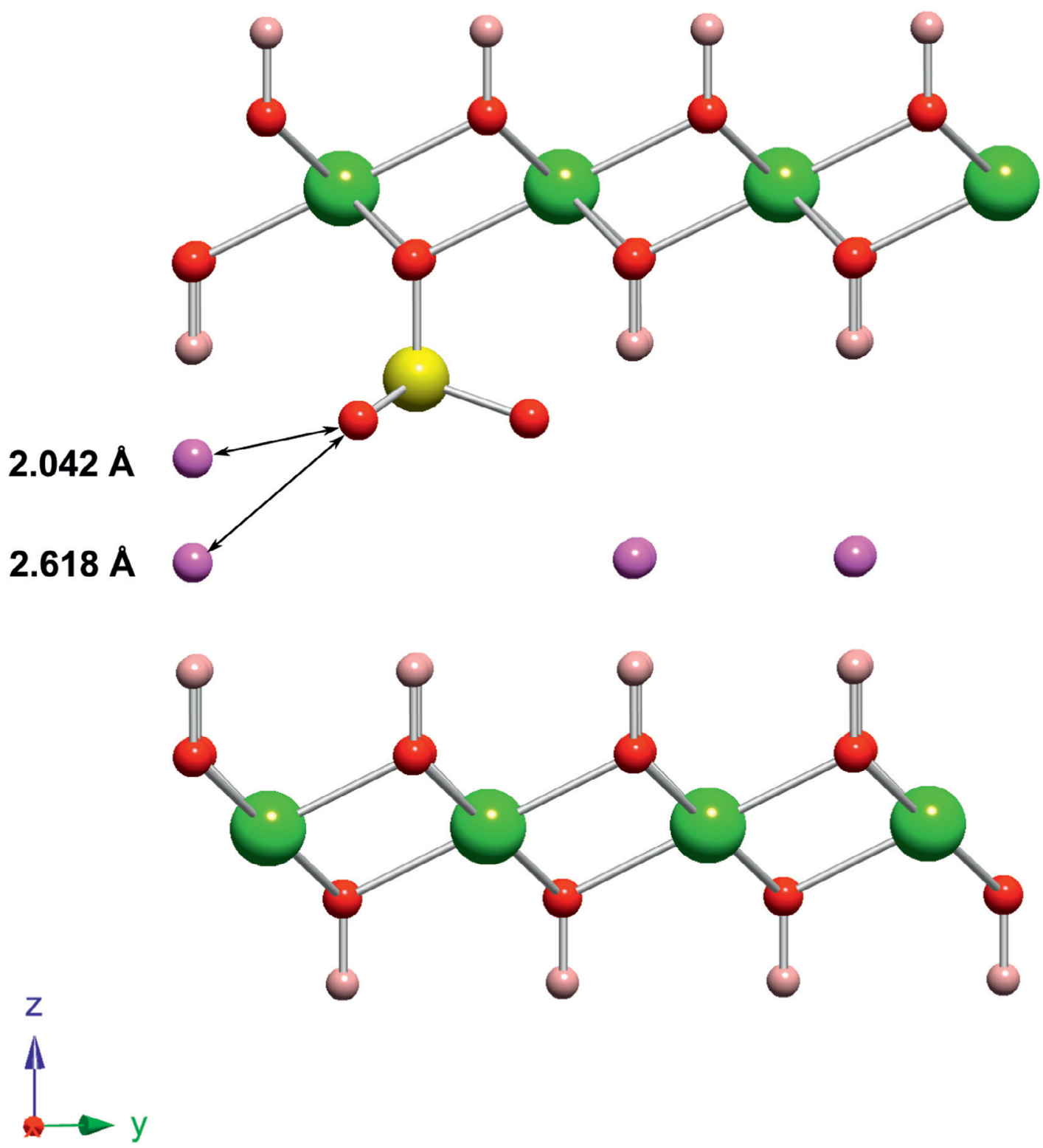

FIG. 6. A sulfate group attached to the upper "brucite" layer implies that immediately neighboring $\mathrm{H}_{2} \mathrm{O}$ molecules must be at the lower position, and vice versa.

$\AA$ (Hawthorne et al. 2000), we can estimate coordinates for the sulfur and the rest of the associated oxygen atoms. Table 3 shows a partially complete model of the average structure, including some atoms that were not detected in the structure refinement owing to the low occupancy of their sites. A position has been estimated for the hydroxide hydrogen atom, based on an $\mathrm{O}-\mathrm{H}$ distance of $1.03 \AA$ ( 0.8 v.u. $)$, but not for the hydrogen atoms of $\mathrm{H}_{2} \mathrm{O}$.
In order to avoid impossibly small distances between oxygen atoms of two different sulfate tetrahedra, a sulfate group cannot have a second sulfate tetrahedron replacing any of the six immediately neighboring $\mathrm{OH}^{-}$groups of the same layer, if the sulfate tetrahedra are oriented similarly (Fig. 4). Also, there is insufficient space for two sulfate groups to face each other across the interlayer (Fig. 5). These steric factors limit the maximum value of sulfate 

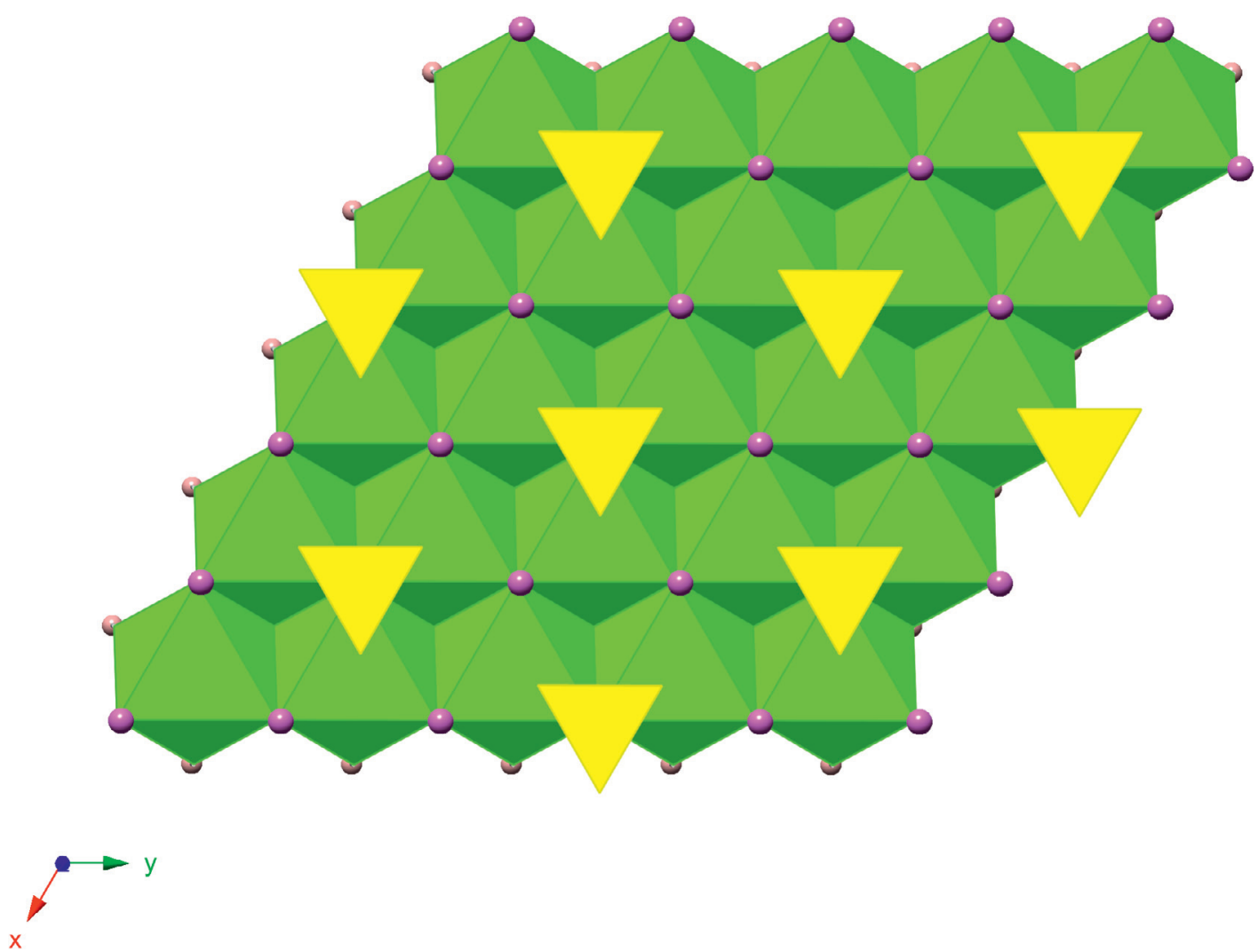

FIG. 7. The densest possible occupancy of sulfate groups attached to one side of a given "brucite" layer, with one-third of the hydroxide groups replaced. This density of sulfate occupancy can only be achieved if all sulfate tetrahedra are at the 'lower' position and all $\mathrm{H}_{2} \mathrm{O}$ (pink) are at 'upper' positions, or vice versa.

content $x$ to $1 / 3$. However, it will be seen below that consideration of sulfate-water interactions may impose even tighter constraints upon the maximum value of $x$.

Although the XRD results indicate that there is no long-range order of sulfate and $\mathrm{H}_{2} \mathrm{O}$ positions in jamborite, steric considerations imply considerable coupling between their local occupancy patterns. It is obvious that if $\mathrm{S}$ replaces $\mathrm{H} 1$ above a given $\mathrm{O} 1$ atom, then there is no room for $\mathrm{H}_{2} \mathrm{O}$ at either of the split Ow positions at the same $x$ and $y$ coordinates in the same interlayer. The distances from $\mathrm{O} 2$ of a sulfate group to the neighboring Ow sites are also short enough that there is coupling between sulfate and $\mathrm{H}_{2} \mathrm{O}$ occupancies (Fig. 6). If a sulfate group is attached to the upper "brucite" layer, then $\mathrm{H}_{2} \mathrm{O}$ molecules at the "upper" position would be at only 2.042 $\AA$ from the nearest sulfate oxygen atom, whereas the corresponding "lower" positions are at $2.618 \AA$. Hence, an "upper" sulfate must be surrounded by $\mathrm{H}_{2} \mathrm{O}$ molecules at the "lower" position, and vice versa.
Thus, the double interlayer of $\mathrm{H}_{2} \mathrm{O}$ apparent from the structure refinement occurs because a sulfate group attaches randomly either to the "brucite" layer below or to the one above, and drives the neighboring interlayer $\mathrm{H}_{2} \mathrm{O}$ molecules to adopt either of two different $z$ coordinates. The maximum number of $\mathrm{H}_{2} \mathrm{O}$ per formula unit $\mathrm{Ni}^{2+}{ }_{1-x} M^{3+}{ }_{x}(\mathrm{OH})_{2-x}\left(\mathrm{SO}_{4}\right)_{x} \cdot n \mathrm{H}_{2} \mathrm{O}$ is thus $n=(1-x)$, but as this number is spread over a site with four times the multiplicity of the $M$ site, the maximum occupancy of the Ow site is only $(0.5-$ $x / 2$ ) (Table 3). The mean composition of jamborite in this study is $x=0.1$, such that the maximum Ow occupancy in the structure model is 0.45 (Table 3 ). This value is in almost perfect agreement with the occupancy of 0.44 obtained from the structure refinement, which both supports the correctness of the model and implies that jamborite is indeed fully hydrated.

It was noted above that in order to ensure an adequate distance between sulfate groups, $x$ cannot exceed $1 / 3$. However, for this composition, every $\mathrm{H}_{2} \mathrm{O}$ molecule in an interlayer is adjacent to three $\mathrm{SO}_{4}$ 

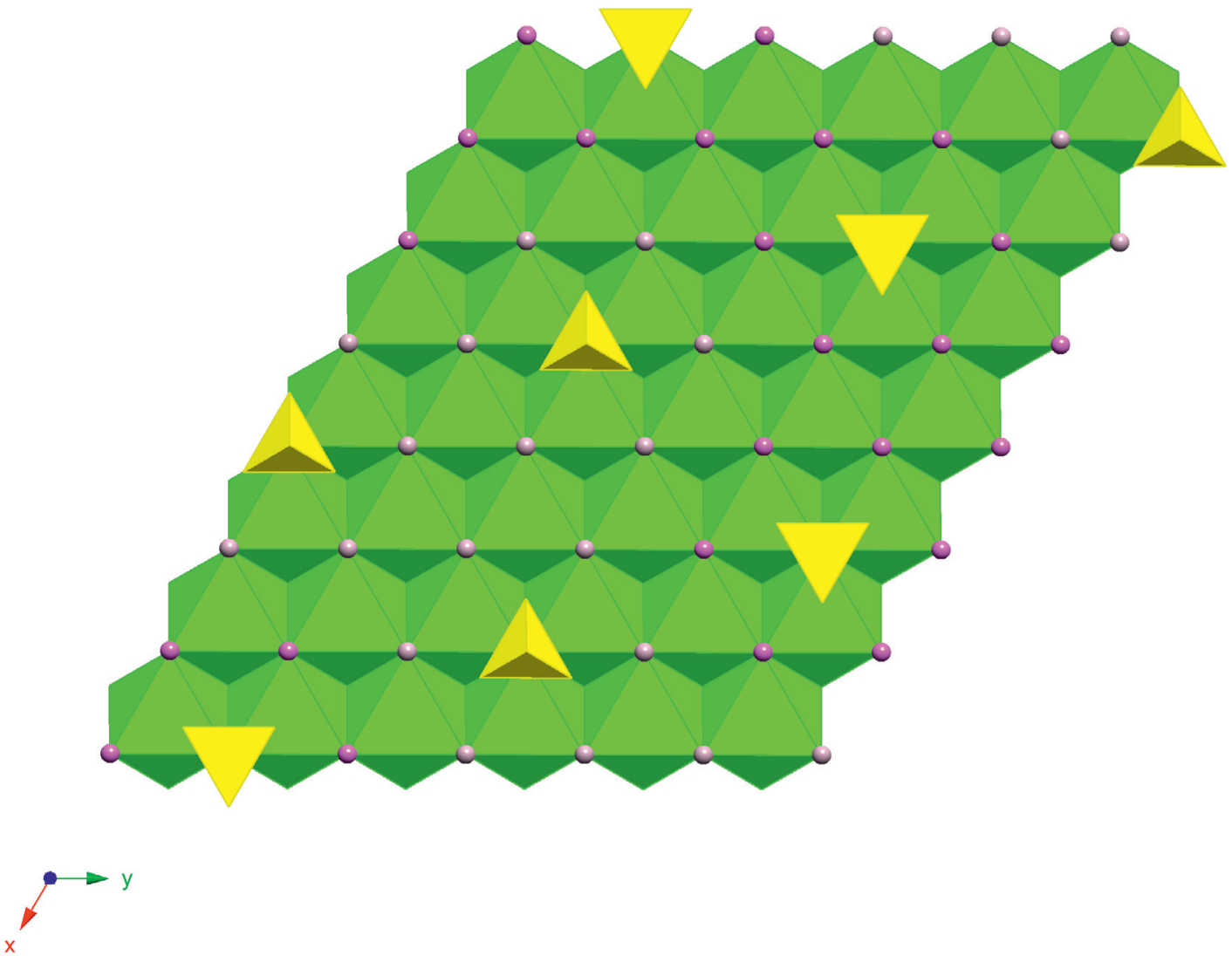

FIG. 8. "Brucite" layer of jamborite, showing the densest possible packing of sulfate tetrahedra in the overlying interlayer for which there is no short-range coupling between up/down orientations of sulfate tetrahedra, corresponding to the composition $x=1 / 7$. Sulfate tetrahedra point downward and bond to the underlying "brucite" layer, or point upwards and bond to the "brucite" layer above, with equal probability. Downward-pointing tetrahedra are surrounded by $6 \mathrm{H}_{2} \mathrm{O}$ at the 'upper' position (saturated pink color), whereas upward-pointing tetrahedra are surrounded by $6 \mathrm{H}_{2} \mathrm{O}$ at the 'lower' position (pinkish-grey color).

groups (Fig. 7). Because $\mathrm{H}_{2} \mathrm{O}$ must occupy the 'upper' position if any adjacent $\mathrm{SO}_{4}$ group is at its 'lower' position and vice versa, the only way that such a high value of $x$ can be accommodated is if all $\mathrm{SO}_{4}$ groups in a given layer are at the same height, as are all $\mathrm{H}_{2} \mathrm{O}$ molecules. Thus, there would have to be complete two-dimensional upper-lower order within a single interlayer, and equal occupancy of the two $\mathrm{H}_{2} \mathrm{O}$ positions in the average structure can then only occur through lack of correlation between successive interlayers. In order to avoid any coupling between the heights of neighboring sulfate groups, each $\mathrm{H}_{2} \mathrm{O}$ molecule must be adjacent to at most one sulfate group. Hence, there must be at least two $\mathrm{H}_{2} \mathrm{O}$ molecules between each pair of sulfate groups, which is only possible up to a maximum $x=1 / 7$ (Fig. 8). The up or down orientations of individual sulfate tetrahedra are now quite independent of one another, although each sulfate group determines the position of the sextet of $\mathrm{H}_{2} \mathrm{O}$ molecules that surround it. The even lower value $x$ of 0.1 that is observed for jamborite suggests that sulfate heights are disordered in this fashion, such that the sextets of $\mathrm{H}_{2} \mathrm{O}$ surrounding them occur at both heights equally; $\mathrm{H}_{2} \mathrm{O}$ groups also exist that are not adjacent to any sulfate groups, and these can occupy either height randomly.

\section{DEFINITION OF JAMBORITE}

In our crystal structure refinement, the feature that distinguishes jamborite from all related minerals described to date is the double layer of partially occupied $\mathrm{H}_{2} \mathrm{O}$ sites. We show above that the splitting of the $\mathrm{H}_{2} \mathrm{O}$ layer can be ascribed to avoidance of $\mathrm{SO}_{4}$ groups which bond directly to octahedral cations either above or below, unlike the interlayer anions of 
the hydrotalcite supergroup. The occupancy of the $\mathrm{SO}_{4}$ groups themselves is so low in the average structure that they cannot be located in the refinement, but the $\mathrm{S}$ content is readily analyzed by EDS, and Raman spectroscopy confirms its speciation. Replacement of $\mathrm{OH}^{-}$by $\mathrm{SO}_{4}{ }^{2-}$ is charge-balanced by substitution of a trivalent cation for $\mathrm{Ni}^{2+}$, and $\mathrm{Co}^{3+}$ predominates by far as the trivalent species in the sample studied. Thus, we propose that the name "jamborite" applies to the species with the structure type refined here and the composition $M^{2+}{ }_{1-x} M^{3+}{ }_{x}(\mathrm{OH})_{2-x}\left(\mathrm{SO}_{4}\right)_{x} \cdot n \mathrm{H}_{2} \mathrm{O}$, where $M^{2+}$ is predominantly $\mathrm{Ni}$ and $M^{3+}$ is predominantly Co. Compositions where trivalent cations other than $\mathrm{Co}$, or anions other than sulfate, are dominant would represent different species. In particular, it is easy to envisage the possible occurrence of an $\mathrm{Fe}^{3+}$ -dominant analogue. However, the fact that we have not detected such a phase, when $\mathrm{Ni}^{2+}-\mathrm{Fe}^{3+}-\mathrm{SO}_{4}$ members of the hydrotalcite supergroup are well known (honessite and hydrohonessite), suggests that the $\mathrm{Fe}^{3+}$ analogue is of limited stability at best.

\section{OCCurrence of Jamborite, Honessite, And HYDROHONESSITE}

Jamborite has been reported from about twenty locations ( $c f$. www.mindat.org), mostly replacing millerite, as described in the original article by Morandi \& Dalrio (1973). We doubt that all of these occurrences are actually jamborite; many may be of visually similar green secondary minerals. Specimens from Hoopeston, Illinois and Halls Gap, Kentucky, USA, were analyzed at Museum Victoria and were identified as hydrohonessite rather than jamborite or honessite. However, as noted in the introduction, we reconfirmed by powder XRD, EDS, and Raman spectroscopy that the specimens from $\mathrm{Ca}^{\prime}$ de' Ladri, Monteacuto Ragazza, and Castelluccio di Moscheda do contain jamborite, although much material of similar appearance and composition from these localities as well as Rio Vesale is amorphous to X-rays. Honessite similarly appears to be rare, with specimens converting readily to hydrohonessite, although honessite from the type locality (Lindon, Wisconsin, USA) has remained stable and has not converted to hydrohonessite. Nickel \& Wildman (1981) and Bish \& Livingstone (1981) noted that honessite and hydrohonessite interconvert readily, depending on temperature and humidity. In nature, jamborite occurs rarely as a first stage in the alteration of millerite to hydrotalcitesupergroup minerals. This is consistent with its less oxidized composition $\left[\mathrm{M}^{3+} /\left(\mathrm{M}^{2+}+\mathrm{M}^{3+}\right)=0.10\right.$ for the jamborite of this study, but 0.25 for honessite or hydrohonessite]. Our data, and the lack of observation of an $\mathrm{Fe}^{3+}$ analogue to date, suggest that whether it forms or not depends on the availability of cobalt. As alteration proceeds, the progressively more hydrated phases honessite and then hydrohonessite replace it.

\section{Conclusions}

1. The ideal formula for jamborite is now $\mathrm{Ni}^{2+}{ }_{1-x}$ $\mathrm{Co}^{3+}{ }_{x}(\mathrm{OH})_{2-x}\left(\mathrm{SO}_{4}\right)_{x} \cdot n \mathrm{H}_{2} \mathrm{O}$ rather than $\left(\mathrm{Ni}^{2+}\right.$, $\left.\mathrm{Ni}^{3+}, \mathrm{Fe}\right)(\mathrm{OH})_{2}\left(\mathrm{OH}, \mathrm{S}, \mathrm{H}_{2} \mathrm{O}\right)$.

2. Structural investigation shows that jamborite lies outside the hydrotalcite supergroup as defined by Mills et al. (2012).

3. Jamborite is no longer a "questionable species".

\section{ACKNOWLEDGEMENTS}

We thank Paul Pohwat at the Smithsonian Institution and Peter Downes at the Western Australian Museum for loaning portions of the type specimens of honessite and hydrohonessite, respectively. The manuscript took advantage of reviews by Uwe Kolitsch, Robert Martin, and an anonymous reviewer. The research was supported by "Progetto d'Ateneo 2012, University of Firenze" to LB and by project MIUR 101742-2013, co-financed by AMI "Characterization of new and/or rare mineral species" to MEC and EB.

\section{REFERENCES}

Bish, D.L. \& Livingstone, A. (1981) The crystal chemistry and paragenesis of honessite and hydrohonessite: the sulphate analogues of reevesite. Mineralogical Magazine 44, 339-343.

Brown, I.D. \& Altermatt, D. (1985) Bond-valence parameters obtained from a systematic analysis of the Inorganic Crystal Structure Database. Acta Crystallographica B41, 244-247.

Génin, J.-M.R., Mills, S.J., Christy, A.G., Guérin, O., Herbillon, A.J., Kuzmann, E., Ona-Nguema, G., Ruby, C., \& UpADHYAY, C. (2014) Mössbauerite, $\mathrm{Fe}^{3+}{ }_{6}$ $\mathrm{O}_{4}(\mathrm{OH})_{8}\left[\mathrm{CO}_{3}\right] \cdot 3 \mathrm{H}_{2} \mathrm{O}$, the fully oxidized 'green rust' mineral from Mont Saint-Michel Bay, France. Mineralogical Magazine 78, 447-465.

Hawthorne, F.C., Kimata, M., \& Eby, R.K. (1993) The crystal structure of spangolite, a complex copper sulfate sheet mineral. American Mineralogist 78, 649-652.

Hawthorne, F.C., Krivovichev, S.V., \& Burns, P.C. (2000) The crystal chemical of sulfate minerals. In Sulfate Minerals - Crystallography, Geochemistry, and Environmental Significance (C.N. Alpers, J.L. Jambor, \& D.K. Nordstrom, eds.). Reviews in Mineralogy 40, 1-112.

Herrendorf, W. (1993) Habitus. Ph.D. dissertation, University of Karlsruhe, Germany. 
Ibers, J.A. \& Hamilton, W.C. (EDs.) (1974) International Tables for X-ray Crystallography, Volume IV. Kynock, Dordrecht, Netherlands, 366p.

Mills, S.J., Christy, A.G., GÉnin, J.-M.R., Kameda, T., \& Colombo, F. (2012) Nomenclature of the hydrotalcite supergroup: natural layered double hydroxides. Mineralogical Magazine 76, 1289-1336.

Morandi, N. \& DAlrio, G. (1973) Jamborite: a new nickel hydroxide mineral from the northern Apennines, Italy. American Mineralogist 58, 835-839.

Nickel, E.H. \& Wildman, J.E. (1981) Hydrohonessite - a new hydrated Ni-Fe hydroxysulphate mineral; its relationship to honessite, carrboydite and minerals of the pyroaurite group. Mineralogical Magazine 44, 333-337.
OxFord DifFraction (2006) Crysalis RED (Version 1.171.31.2) and ABSPACK in CrysAlis RED. Oxford Diffraction Ltd., Abingdon, Oxfordshire, England.

Sheldrick, G.M. (2008) A short history of SHELX. Acta Crystallographica A64, 112-122.

Stoe \& CIE (1996) X-shape (version 1.02). Stoe \& Cie, Darmstadt, Germany.

WoJdYR, M. (2010) Fityk: a general-purpose peak fitting program. Journal of Applied Crystallography 43, 1126-1128.

Received June 13, 2014, Revised manuscript accepted November 23, 2014. 